\title{
Sanitation Practices among Food Handlers in a Military Food Service Institution, Malaysia
}

\author{
Hai Yen Lee, Wan Nadirah Wan Chik, Fatimah Abu Bakar, Nazamid Saari, Nor Ainy Mahyudin* \\ Food Safety Research Centre (FOSREC), Department of Food Science and Technology, Universiti Putra Malaysia, Serdang, Ma- \\ laysia. \\ Email: *norainy@food.upm.edu.my
}

Received October $3^{\text {rd }}, 2012$; revised November $3^{\text {rd }}, 2012$; accepted November $10^{\text {th }}, 2012$

\begin{abstract}
This study was conducted over a period of two months to assess the food hygiene practices among food handlers in a military food service institution that have been trained with food safety practices and knowledge. Since limited data was published for the services rendered to governmental agencies such as the military, this study was conducted to determine the level of knowledge, attitude and motivation of food handlers under this institution that was responsible for the provision of food to the armed forces in Malaysia. Findings from this study offered an insight for food sanitation practices and influence of the authority towards food service institutions under the policy of voluntary HACCP practices.
\end{abstract}

Keywords: Hygiene; Practices; Food Service Institutions; Malaysia

\section{Introduction}

Food safety has increasingly gaining attention of authorities worldwide from the cases of food borne outbreaks. An increase in the diseases related to food borne illnesses have been seen from 2005 to 2008 in Malaysia [1,2]. Occurrence of food borne illnesses can be attributed to many factors, one of it is the handling process of food preparation especially by food handlers. This is because hand can be a vector of dissemination of pathogens through cross contamination [3]. The Good Hygiene Practices describes "all practices regarding the conditions and measures necessary to ensure the safety and suitability of food at all stages of the food chain" [4] which is an important process that eventually lead to the safety in the kitchen. It covers proper storage of food items, maintenance of clean environment during food preparation and assurance of all dishes served are clean and free of bacteria that can potentially cause further contamination and prevent food borne illnesses.

Clayton et al. [5] stated that a high proportion of food poisoning outbreaks can still occur due to poor food handling practices even though the number of food handlers that received the food hygiene education is high. It has been known that provision of food handling education can influence the food handling practices as it is based on the certified food hygiene program which was designed using the KAP model. According to Seaman and Eves [6], KAP model assumes that knowledge (K), of an indi-

\footnotetext{
"Corresponding author.
}

vidual will influence the practice, and provide a basis of information which will subsequently lead to a direct change in attitude (A) and consequently in practices (P). KAP model is a representative study of specific population to collect information on what is known in relation to a particular topic in order to understand the knowledge, attitude and practices in basic food handling. The effecttiveness of KAP is still debated and criticized in several studies [7-11] stating that the knowledge of food safety issues does not always bring a positive change in food handling behaviour among the food handlers. However, attitude plays an important role that will ensure the reduction in the trend of foodborne illnesses [12]. Study by Howes [10] indicated that there is a correlation between positive attitude and continued education of food handlers towards the maintenance of safe food handling practices.

Institutional foodservice, also known as non-commercial food service is defined as food service that functions without the objective of making profit [13]. Walker [14] stated that institutional food service are operations that serve people who are members of particular societal institution such as hospital, schools, nursing homes, military and industry. Military food service operation is a large and important component in the management of food safety. This is because the military is a high risk group for food poisoning due to the community kitchen practice [15]. Due to the increment in the incidence of food borne diseases and the increased local surveillance 
in foods due to contamination of Campylobacter, Vibrio parahaemolyticus, Bacillus cereus, [16-18], this revealed data gap on the assessment on hygienic practices in local food service in stitutions. Military foodservice operation is a large and important component of managed service. According to Walker [14], feeding the military personnel includes feeding the troops and officers in clubs, dining halls and military hospitals as well as in the field and described the basic services that start with purchasing, storing, issuing, preparation and serving. These services are organized to manage the flow of foods provided to the personnel and classified as non-profit institutions. In Malaysia, food preparation for the military can be outsourced or self-operated. The outsourcing service awarded to a company will be contracted for food catering to the military camps for 15 years. As few and very limited studies have reported on the food service practices especially for government institution locally, this study was conducted to assess the attitude and practices in food safety among food handlers in the military food service institution and the role of socio demographic factor (salary) in the motivation to increase the work quality among the food handlers.

\section{Materials and Methods}

\subsection{Research Design and Location}

This cross sectional study was carried out over a period of two months from May to June 2011. The location of the study was in Klang Valley (Kuala Lumpur Territory and Selangor State) involving eleven military institutions consisting of six air forces camps, one military hospital, three military camps and two other military institutions.

\subsection{Ethical Issue}

Ethical considerations were given to the following: collection of information, seeking consent, provision of incentives, obtaining sensitive information, potential of harm to participants and maintaining confidentiality [19]. At inception of the study, a signed informed consent will be obtained from all food handlers who participated in this study.

\subsection{Sample Size and Sampling Method}

A total of 222 respondents from the central kitchen participated in this study. The questionnaire was self-administered and prepared based on Nurul Huda [20]. The modified questionnaires consist of five parts. The first part was designed to collect demographic information of the respondents. Second part consists of questions on attitude of the food handlers towards food safety. Food handlers were asked score their level of agreement to the statements using a five-point rating scale for part three (strongly disagree $=1$, disagree $=2$, neither agree/dis- agree $=3$, agree $=4$, strongly agree $=5$ ). Part three consists of 42 questions covering observed practices in military food service institution which includes practices of food temperature and time control, personal hygiene, storage of food in refrigerator or freezer, dry storage, ware washing practices, facilities in the working environment, garbage storage, disposal and pest control. Part four was related to the motivation to improve the quality of work among the food handler. Respondents were asked to choose either "yes" or "no". The score range was between 0 to 15 , which was converted to percentage. The score below $50 \%$ of food safety knowledge questionnaire is defined as poor knowledge. Part five consist of three questions which were related to the increase of quality of work among food handlers in the institution.

\subsection{Pilot Test}

Questionnaires went under a pilot test consisting of 30 personnel in a military camp that were not included in the final survey. Using Cronbach Alfa test, the reliability coefficient was 0.70 [21]. As a result of the item analysis, several test questions were modified to improve the clarity of the survey questionnaires.

\subsection{Data Analysis}

All statistical analyses were conducted using SPSS 17. ANOVA was used to assess the differences in sociodemographic and food safety practices among managers, cooks, and other food service employees. Food safety practice score was calculated for each facility based on researcher observations to determine an overall assessment of the operation for purposes of comparison. Multiple linear regression analysis was conducted to determine the relationship between motivation and quality of work score. Test parameters such as gender, ages, education level, working experience and exposure to training courses were compared using independent sample t-test and ANOVA (confidence interval 95\%).

\section{Results and Discussion}

The military food service institution in this study had nine camps which consist of 222 respondents in various responsibilities. When the employees respond to the survey have been evaluated according to their job description, it has been found that $33.8 \%$ of them were staff responsible for service and $24.3 \%$ are chefs, $12.6 \%$ of them are cutter and supervisor, $7.7 \%$ are the dishwashers appointed for other works except cooking and $6.8 \%$ are the storekeeper. Most managers are men. There are $44.6 \%$ respondents involved in this study are male, and 55.4\% are female. Majority (96.8\%) are Malay, Chinese are $(0.5 \%)$ and others are $(2.7 \%)$ while the average mean for the age is 26.4. Education level for majority of the re- 
spondents $(90.5 \%)$ is secondary school compared with primary school $(2.7 \%)$ and without formal education $(0.5 \%)$ while others $(6.3 \%)$. Majority of the respondents $(40.5 \%)$ had less than one or one to five years of working experience and the least are $3.6 \%$ with more than eleven to twenty years of experience. A number of 145 respondents $(65.3 \%)$ received salary in range of RM 501 - RM 1000 while only $0.9 \%$ are paid more than RM 3000 per month. Only $84.2 \%$ of the participants had attended food training courses where $15.8 \%$ of them are not attended these courses. About $98.6 \%$ accepted injection of Thypim $\mathrm{Vi}$ before being hired. The result of Table 1 indicates that the safe food-handling is the most important factor of employee's attitude towards food safety. Also the result indicated that the employee disagreed that "army can get easily food borne illness" but they agreed that the "safe food handling were their responsibility". The spread of food borne illnesses in food establishment has been associated to improper food handling practices in $97 \%$ of the cases [10]. It is not uncommon for food handlers to be unaware of the association of hand contamination with food safety practices in the agricultural sector [9].In comparison to a study in Ireland [22], more kitchen staff from this study have undergone formal training. Recommendation of Typhim Vi vaccination to food handlers were complied and is an important GHP stipulation.

In the dimension of observed practices in military food service institution, the respondents were found to be knowledgeable about food safety practice. The results are shown below in Table 2. Both proper as well as inappropriate food-handling practices were observed in the military feeding institution. Areas identified for more positive improvements are: adequate cooking temperature and usage of thermometers, appropriate uniforms and limitation of jewellery adornments, proper storage of foods including the proper separation of raw and cooked foods; inventory rotation and chemical storage, appropriate ware washing and well-maintained facilities. Food service workers were usually involved with setting up the dining room and serving meals to the army. The hair restraints were used in every central kitchen by the workers. Many food service operations did not record food temperatures. Although the end-point cooking temperatures were taken in four out of the eleven camps, they were recorded in an appropriate way, which was noted down in the temperature form but not documented in a file. Stem-type thermometers were most commonly used but accuracy issues may arise as many employees reported that they did not calibrate the thermometers. For food temperatures that were taken by the researcher, temperatures of cold foods were frequently found to be above the recommended $5^{\circ} \mathrm{C}$. Effectiveness of sanitizing procedures was not observed in the central kitchen too. Regular checks on sanitizer concentration was not conducted by the food service sstaff and much less commonly recorded. Diluted sanitizers (detergent mixed with sanitizer) were observed in some operations in order to facilitate the cleaning process however it also reduces the effect-

Table 1. Mean and standard deviation scores of food handler's attitude towards food safety based on 5-point rating scale responses.

\begin{tabular}{lcc}
\hline Attitude statement & Mean & SD \\
\hline I am responsible for making sure that foods served to army are safe. & 4.64 & 0.033 \\
Safe food handling is an important part of my job responsibilities. & 4.67 & 0.032 \\
I believe that how I handle food relates to food safety & 4.61 & 0.033 \\
Learning more about food safety is important to me & 4.64 & 0.042 \\
Army can easily get food borne illness. & 4.07 & 0.078 \\
Certification in food safety helps a foodservice employee prepare and serve safe food to army. & 4.59 & 0.036 \\
\hline
\end{tabular}

Table 2. Scores of observed practices in military food service institution.

\begin{tabular}{lcccc}
\hline \multirow{2}{*}{ Observed practices and dimensions } & \multicolumn{2}{c}{ Yes } & & No \\
\cline { 2 - 5 } & Average & SD & Average & SD \\
\hline Practice of time and temperature control & 92.96 & 6.70 & 6.96 & 1.27 \\
Personal hygiene & 98.73 & 1.26 & 1.45 & 2.70 \\
Practice of keeping food in refridgerator/freezer & 98.48 & 1.64 & 2.33 & 1.70 \\
Practice of keeping food in dry storage & 97.30 & 1.56 & 6.10 & 1.08 \\
Practice of warewashing & 97.67 & 6.36 & 1.08 & 6.43 \\
Practice of facility in the working environment & 93.83 & 97.52 & & 2.48 \\
Practice of garbage storage, disposal and pest control & & & 1.75 \\
\hline
\end{tabular}


tiveness of the sanitizers. Ware washing temperatures or sanitizing concentrations level were documented the entire central kitchen which is a good food handling practices. Proper labelling was observed in the entire central kitchen outlet. This study identified that proper filing and documentation of the observation of temperature and sanitizing detergents for washing should be improved.

Tabulated as Table 3 is the results showing motivational question 8 (good recognition system would motivate the employee) has the highest mean (4.65) and it followed by motivational question 6 (rewards can improve employee's performance) which is 4.64 . Motivation question number 1 (I like my job) has the least important to improve the quality of work among the food handler with the mean of (4.31). Motivation is defined as psychological forces that determine the direction of a person's behavior in an organization, a person's level of persistence [23]. This may be the key to the effectiveness of the organization and an understanding to the applied psychology of motivation in a workplace, known as organizational behaviour, can increase the workforce motivation. A total of $5.8 \%$ of total variance can be explained by the eight attribute of motivation questions. The result indicates that only question number 6 (rewards can improve employee's performance) and motivation question number 7 (same rewards will motivates the employee) has significant effect to quality.

In Table 4, the food handlers responded to questionnaires that may increase their motivation and quality of work. The highest mean is for the question number 2 (job satisfaction), is (4.82) while the lowest mean is the ques- tion 3 (attending short training) is (4.51). Implementation of food safety practices among food handlers in the food service institution were correlated to the sociodemographic factor of salary. Question for practices factor, which are the question number 11 (eating, drinking and chewing gum are prohibited during food preparation), question number 13 ( smoking is prohibited in the central kitchen), question number 17 ( the inventory rotation is practiced), question number 31 (walls, floors, ceilings and lighting are adequate for food production), question number 32 (premise maintained), question number 36 (nonfood contact surfaces are clean and maintained), and question number 38 (garbage are clean) shows the significant difference between the salary and practices factor. Based on statistical analyses, two questions that showed to have significant effect on motivation were question number 6 "Rewarding employees give effect on their performance" $(\mathrm{t}=2.101 ; \mathrm{p}=0.037)$ and motivation question number 7 "Every employee is motivated by the same reward" $(t=-2.782, p=0.006)$. The other variable does not have significant effect on quality. It has been well acknowledged that education and training of the food handlers plays an important role in the knowledge and attitude of food handlers [24]. However, application of practice of the knowledge and attitude in the working environment may not be prevalent, because as high as $63 \%$ of food handlers admitted of not practicing these behaviors fully [5].

This study was conducted to evaluate the status of food hygiene practices for the military institutions. In general, the scores obtained for each dimension is higher

Table 3. Mean and standard deviation scores on motivation to improve the quality of work among the food handler based on 5-point scale rating.

\begin{tabular}{|c|c|c|}
\hline Motivation statement & ${ }^{\mathrm{a}}$ Mean & ${ }^{\mathrm{b}} \mathrm{SD}$ \\
\hline I like my job & 4.31 & 0.032 \\
\hline Managers/supervisors actions impact those with whom I work. & 4.45 & 0.036 \\
\hline How supervisors communicate with employee can serve as a motivator for them. & 4.39 & 0.044 \\
\hline Supervisors can influence subordinates by talking nicely to them & 4.49 & 0.044 \\
\hline If employees were paid more for handling food safely, they would do it & 4.59 & 0.052 \\
\hline I believe that rewarding employees will give effect on their work performances. & 4.64 & 0.035 \\
\hline Every employee is motivated by the same rewards. & 4.48 & 0.043 \\
\hline If I had a good recognition system in place, all of my employees would be motivated. & 4.65 & 0.036 \\
\hline
\end{tabular}

Table 4. Scores for 5-point scale rating on the quality of work among food handler food service institution.

\begin{tabular}{lcc}
\hline Quality of statement & Mean & SD \\
\hline Giving off-day or reward to me will give motivation to work harder. & 4.66 \\
Job satisfaction will increase my quality of work. & 4.82 \\
$\begin{array}{l}\text { Attending short training in relevant industry or organisation will increase my quality of work. } \\
\text { (e.g.: attending short training in hospital food service, food catering.) }\end{array}$ & 0.734 \\
\hline
\end{tabular}


than other reported studies, however, constant evaluation has to be carried out to ensure the perpetuation of the hygienic practices. Other than that, positive reinforcements from the food hygiene training can be carried out by the management through various ways such as increasing reward and motivation to the food hygiene workers. Currently, Malaysia's food policy recommends HACCP on a voluntary basis. As it was observed that the HACCP in the food service institution in this study was implemented, improvements and suggestions have been forwarded to further increase the hygienic system in the institution. Recommendation to look into the HACCP and proper filing of documentation and practice can further assure the military service of the quality of food in the camps.

\section{Acknowledgements}

This study was supported by Universiti Putra Malaysia Research University Grant Scheme.

\section{REFERENCES}

[1] Ministry of Health Malaysia, "Statistik e-FaktaKesihatan," 2012. http://www.moh.gov.my/v/stats_si.

[2] N.-A.Abdul-Mutalib, M.-F. Abdul Rashid, S. Mustafa, S. Amin-Nordin, R. AwangHamat and M. Osman, "Knowledge, Attitude and Practices Regarding Food Hygiene and Sanitation of Food Handlers in Kuala Pilah, Malaysia," Food Control, Vol. 27, No. 2, 2012, pp. 289-293. doi:10.1016/j.foodcont.2012.04.001

[3] M. Bas, A. S. Ersun and G. Kıvanç, "The Evaluation of Food Hygiene Knowledge, Attitudes, and Practices of Food Handlers in Food Businesses in Turkey," Food Control, Vol. 17, No. 4, 2006, pp. 317-322.

[4] FAO, "Fisheries and Aquaculture Topics. Hygiene and Fish Safety. Topics Fact Sheets," 2012. http://www.fao.org/fishery/topic/12328/en

[5] D. A. Clayton, C. J. Griffith, P. Price and A. C. Peters, "Food Handlers' Beliefs and Self-Reported Practices," International Journal of Environmental Health Research, Vol. 12, No. 1, 2002, pp. 25-39.

[6] P. Seaman and A. Eves, "The management of Food Safety-The Role of Food Hygiene Training in the UK Service Sector," Hospitality Management, Vol. 25, No. 2, 2006, pp. 278-296

[7] D. M. Rennie, "Evaluation of Food Hygiene Education," British Food Journal, Vol. 96, No. 11, 1994, pp. 20-25.

[8] D. M. Rennie, "Health Education Models and Food Hygiene Education," Journal of the Royal Society of Health, Vol. 115, No. 2, 1995, pp. 75-79. doi: $10.1177 / 146642409511500203$

[9] J. E. Ehiri, G. P. Morris and J. McEwen, "Evaluation of a Food Hygiene Training Course in Scotland," Food Control, Vol. 8, No. 3, 1997, pp. 137-147. doi:10.1016/S0956-7135(97)00005-4
[10] M. Howes, S. McEwen, M. Griffiths and L. Harris. "Food Handler Certification by Home Study: Measuring Changes in Knowledge and Behavior," Dairy, Food and Environmental Sanitation, Vol. 16, 1996, pp. 737-744.

[11] S. C. Powell, R. W. Attwell and S. J. Massey, "The Impact of Training on Knowledge and Standards of Food Hygiene-A Pilot Study," International Journal of Environmental Health Research, Vol. 7, No. 4, 1997, pp. 329334. doi:10.1080/09603129773788

[12] O. N. Siow and N. Abdullah Sani. "Assessment of Knowledge, Attitude and Practices (KAP) among Food Handlers at Residential Colleges and Canteen Regarding Food Safety," Sains Malaysiana, Vol. 40, No. 4. 2011, pp. 403-411

[13] L. H. Kotschevar and M. R. Escoffier, "Management by Menu," 2nd Edition, National Restaurant Association Education Foundation, Washington DC, 1994

[14] T. Walker, "Service as a Pathway to Political Participation: What Research Tells Us," Applied Developmental Science, Vol. 6, No. 4, 2004, pp. 183-188. doi:10.1207/S1532480XADS0604_4

[15] M. M. S.Mustafa, S. Jain and V. K. Agrawal, "Food Poisoning Outbreak in a Military Institution," Medical Journal Armed Forced India, Vol. 65, No. 3, 2009, pp. 240243. doi:10.1016/S0377-1237(09)80013-0

[16] L. C. Chai, T. Robin, U. M. Ragavan, J. W. Gunsalam, F. A. Bakar, F. M. Ghazali, S.Radu and P. M. Kumar, "Thermophilic Campylobacter spp. in Salad Vegetables in Malaysia," International Journal of Food Microbiology, Vol. 117, No. 1, 2007,pp. 106-111. doi:10.1016/j.ijfoodmicro.2007.02.014

[17] R. Tunung, L. C. Chai, M. R.Usha, G. B. Patrick, M. G. Farinazleen, A. B. Fatimah, K. M. Pradeep and R. Son. "Incidences and Characterization of Salmonella Species in Street Foods and Clinical Samples," Journal of Food Safety, Vol. 27, No. 4, 2007, pp. 345-361. doi:10.1111/j.1745-4565.2007.00089.x

[18] H. Y. Lee, L. C. Chai, S. Y. Tang, S. Jinap, F. M. Ghazali, Y. Nakaguchi, M. Nishibuchi and R. Son, "Application of MPN-PCR in Biosafety of Bacillus cereus s.l. in Readyto-Eat Cereals," Food Control, Vol. 20, No. 11, 2009, pp. 1068-1071. doi:10.1016/j.foodcont.2009.01.009

[19] R. Kumar, "Research Methodology-A Step-by-Step Guide for Beginners," 2nd Edition, Sage, London, 2005.

[20] N. Huda, "Tahap Pengetahuan, Sikap Dan Amalan Kebersihan Dan Keselamatan Makanan di Kalangan Pengendali Makanan di Hospital." MSc Thesis, Universiti Kebangsaan Malaysia, Bangi, 2008.

[21] J. R. A. Santos, "Cronbach's Alpha: A Tool for Assessing the Reliability Scales," Journal of Extensions, Vol. 37, No. 2, 1999. http://www.joe.org/joe/1999april/tt3.php

[22] D. J. Bolton, A. Meally, I. S. Blair, D. A. McDowell, C. Cowan, "Food Safety Knowledge of Head Chefs and Catering Managers in Ireland," Food Control, Vol. 19 No. 3, 2008, pp. $291-300$

[23] G. R. Jones and J. M. George, "Contemporary Management," 5th Edition, McGraw-Hill Irwin, New York, 2008.

[24] P. S. Toh and A. Birchenough, "Food Safety Knowledge 
and Attitudes: Culture and Environment Impact on Hawkers in Malaysia: Knowledge and Attitudes Are Key Attributes of Concern in Hawker Food Handling Practices and Outbreaks of Food Poisoning and Their Prevention," Food Control, Vol. 11, No. 6, 2000, pp. 447-452. doi:10.1016/S0956-7135(00)00008-6 